\title{
Quality of Life of Patients with HIV/Tuberculosis Coinfection Experiencing Nursing Consultation
}

\author{
Alexsandra Rodrigues Feijão1, \\ Elucir Gir², Marli Teresinha Gimeniz Galvão ${ }^{3}$
}

\section{Abstract}

Background: The aim was to evaluate changes that systematic nursing consultations based on Orem's theory create in quality of life of people that live with HIV, and who are under tuberculosis (TB) treatment.

Method: A study developed in Fortaleza, in northeastern Brazil, from September 2009 until October 2010. A group of 96 people infected by HIV and in TB treatment participated. And 48 integrated the exposed group, which was monitored by nursing consultations based on Orem's theory. The other participants were in the non-exposed group, monitored by conventional treatment. An instrument for sociodemographic and clinic evaluation and the HAT-QoL for quality of life evaluation before and after tuberculosis treatment were used for data collection.

Findings: Among individuals followed by nursing consultation using the Orem foundation, significant improvement was evidenced at the end of the monitoring in the domains: health concerns $(p=0.000)$, general activity $(p=0.000)$, life satisfaction $(p=0.000)$, HIV awareness ( $p=0.000)$, and confidentiality concern $(p=0.000)$. Conclusion: Findings indicated significant improvement of the quality of life indicators evaluated for the intervention group, with the exception of sexual function and financial concerns, aspects that require specific, intersectoral, continued actions.
1 Ph.D. in Nursing. Adjunct Professor, Department of Nursing, Federal University of Rio Grande do Norte.

2 Ph.D. in Nursing. Titular Professor, School of Nursing of Ribeirão Preto, University of São Paulo.

3 Ph.D. in Tropical Diseases. Associate Professor, Department of Nursing, Federal University of Ceará.

\section{Contact information:}

Alexsandra Rodrigues Feijão.

”- alexsandrarf@hotmail.com

\section{Keywords}

Quality of Life; HIV; Tuberculosis Coinfection; Nursing Consultant 


\section{Introduction}

The wellbeing of patients coinfected with HIV/tuberculosis (HIV/TB) is not only determined by their health status or treatment response. For that reason, identification of the factors that determine quality of life is important for directing nursing care to those patients. Therefore, when assessing quality of life (QoL), attention should be paid to both clinical improvement and improvement of subjective wellbeing, sense of vitality, social and emotional bonds [1], mainly when living with pathologies characterized by dense aspects of stigma, prejudice, fear, death expectation, living with the constant ghost of illness and suffering, as in the case of the junction of AIDS and TB.

Nowadays, HIV infection and TB are the most concerning infectious diseases in the world. Both are concentrated in poor regions with minimal resources for diagnosis, treatment and infection control $[2,3]$. These diseases also have an important physiopathological link, in which one infection accelerates the other, generating significant morbidity and mortality. This creates devastating financial and emotional costs to the individuals, their families and society. It is highlighted that, despite decades of investments, many countries maintain high rates of both infections, including the developed countries. However, social disparities present in developing countries raise even further the disease indices [4].

In Brazil, despite the existence of a policy for universal access to antiretroviral therapy (ART) and conditions to establish strategies for TB associated with HIV morbidity and mortality reduction, the country still maintains large numbers of coinfected people with epidemiological relevance. This fact exposes the deficiencies of programs for tuberculosis and HIV control and acts as a barrier to health professionals in defining the diagnosis, evaluation and treatment, due to alterations of symptoms, clinical course and response to recommended treatment of TB in HIVpositive individuals [5]. In this context, nursing has the constant challenge of resituating its practice and its knowledge base for the health promotion reality of that population. The implementation of a structured program also makes the critical evaluation of care possible, facilitating clinical adjustments and multidisciplinary communication [6].

Therefore, goals for QoL improvement through self-care, continuity and completion of treatment based on good adherence can be achieved by nursing consultation and multidisciplinary work. Therapeutic actions related to HIV, as well as TB, seek to enable the improvement of patients' QoL. It is known that QoL encompasses more than therapeutic adherence and there is an important relation between both, especially related to HIV and AIDS.

The study aim was to evaluate the alterations that systematic nursing consultation creates in the QoL of people who live with HIV and are in treatment for TB. For the casuistry, Orem's Self-care Theory was used to support the nursing consultation protocol, because QoL is a factor closed linked to the ability of taking care of one's self.

Thus, it is important to highlight the relevance of using a methodology for care to enhance the health and quality of life of these individuals, when compared to non-systematized care.

\section{Methods}

\section{Location}

The study was developed in the Hospital São José de Doenças Infecciosas (Saint Joseph's Infectious Diseases Hospital - HSJ), a reference center for diagnosis and treatment of people with HIV/Aids in the state of Ceará, in northeastern Brazil. This institution has specialized ambulatory services, and cares for more than $80 \%$ of cases of HIV/TB coinfection in the entire state.

Population and sample: Data collection was conducted between September of 2009 and October of 2010; 96 adult patients (older than 18 years) of both genders with HIV infection and diagnosis of TB 
participated of the study. Inclusion criteria were: TB new cases, as stated by Brazilian Ministry of Health [7], including those who had never received antituberculosis chemotherapy, or received it for less than 30 days. or more than five years ago, or were in retreatment with the basic scheme recently recommended by the National Program to Combat Tuberculosis for beginning treatment of TB (between the first and third months).

The following exclusion criteria were elected: HIV-seronegative patients, patients with cognitive deficits or mental illness that impaired response to questions; institutionalized or homeless; hospitalized patients or patients that had the treatment suspended due to serious side effects.

The sample was defined according to notification at the Hospital São José during the twelve months before the data collection, with a total of 143 cases of coinfection. Appling the inclusion criteria and considering losses, a total of 96 patients were selected. From those, 48 comprised the exposed group and 48 comprised the non-exposed group.

The two groups were formed as: Group 1 (exposed): patients with HIV/TB in medical treatment and monitored through nursing consultations based on Self-care Theory; Group 2 (non-exposed): patients with HIV/TB in medical treatment with non-systemized nursing care.

Patient division into the two groups was randomly performed through simple lottery. Patient recruitment occurred at the beginning of the nursing consultation, after the definition of the inclusion criteria and patient clarification of the research, by signing an informed consent, which also explained the possibility of participating in one of the mentioned groups.

Data collection procedures: during the first nursing consultation for both groups, sociodemographic, epidemiological and clinical data were collected. The variables were: age, marital status, number of children, level of education (schooling), functional status of work/occupation, family income, origin, time of diagnosis of HIV infection, HIV exposure category, beginning of antiretroviral treatment regimen, beginning and ending date of anti-tuberculostatic scheme, signs and symptoms present in the beginning of TB infection, result of Mantoux test (PPD), and presence of associated diseases.

For the exposed group specifically, the patients were monitored through monthly nursing consultations. As described, a model based on Orem's Selfcare Theory was utilized. The non-exposed group was monitored through convention nursing service, also with monthly frequency.

Between the first and third months, and also in the sixth or ninth month of treatment, all patients (exposed and non-exposed groups) were evaluated using the HIV/AIDS-targeted quality of life scale (HAT-QoL), a specific instrument used to evaluate quality of life of individuals with HIV, validated in Brazil [8]. The instrument has 42 items divided in nine domains that investigate the lives of patients in various situations. For all items, five response options known as Likert step descriptors are available. The responses vary from one to five points: one corresponds to the worst QoL state and five corresponds to the best state QoL. The sum obtained was transformed into an analog scale of zero to 100, where zero corresponds to the worst value, and therefore worst QoL, and numbers close to 100 correspond to the best value, or best QoL.

Statistical analysis: the data analysis involved statistical description (absolute and relative frequency, mean and standard deviation). To analyze the association between variables, the nonparametric chisquare $\left(\chi^{2}\right)$ test, Fisher's exact test, linear by linear association test, and Student's t-test were used, as suitable for each type of variable. The differences between the mean related to the HaT-QoL scale scores were compared by Mann-Whitney and Wilcoxon tests. In all statistical, tests the level of significance was set at $p<0.05$. 


\section{Results}

Regarding the evaluation of sociodemographic, epidemiological and clinical characteristics, homogeneity was observed between the groups. However, in general, superiority in the ages of both groups was perceived, with averages of 35.12 and 34.96, respectively. Concerning marital status, $55.3 \%$ of patients in the exposed group had a regular partner (married or in stable union), a finding that showed a slight superiority compared with the non-exposed group. But, as verified, the majority of patients in both groups, a total of 27 and 31 patients, respectively, were without a regular partner at the time of the initial interview.

In both groups, patients presented low levels of schooling, since $68 \%$ of patients had less than nine years of education. Financially, the family income in minimum wages was concentrated overwhelmingly $(80.2 \%)$ in the level of less than or equal to two minimum wages (approximately $\$ 600.00$ ).

A larger frequency of pulmonary TB was verified in both groups (77.1\%). Positive study results for the bacilloscopy were higher $(58.5 \%, p=0.010)$ in the non-exposed group. The majority of the patients in both groups underwent bacilloscopy.

The analysis of the quality of life scale (HAT-QoL) considered the domains whose means were less than 50 points to be impaired. This analysis of the scoring was based on the study of Galvao et al. (2004) [8].

Table 1 shows a comparison between groups during the first nursing consultation. This comparison demonstrates the homogeneity of quality of life before starting the nursing care in each group. All domains were impaired in both groups. The lowest means between domains were related to concerns about the confidentiality of the infection, financial and health concerns. A statistical difference ( $p=$ 0.001) was observed in the financial concerns domain.

To evaluate the outcome of patients during the nursing consultation follow-up, the groups were
Table 1. Comparison of domains of the HAT-QoL scale between groups in the first nursing consultation.

\begin{tabular}{|c|c|c|c|}
\hline Domains & $\begin{array}{l}\text { Exposed } \\
\text { group } \\
\text { Mean + SD }\end{array}$ & $\begin{array}{c}\text { Non-exposed } \\
\text { group } \\
\text { Mean + SD }\end{array}$ & p-value* \\
\hline $\begin{array}{l}\text { General } \\
\text { activities }\end{array}$ & $34.30 \pm 10.01$ & $32.58 \pm 10.71$ & 0.301 \\
\hline Sexual activities & $39.06 \pm 8.79$ & $39.58 \pm 8.15$ & 0.792 \\
\hline $\begin{array}{l}\text { Confidentiality } \\
\text { concerns }\end{array}$ & $17.18 \pm 14.21$ & $19.79 \pm 14.21$ & 0.212 \\
\hline Health concerns & $20.62 \pm 11.32$ & $23.02 \pm 10.03$ & 0.177 \\
\hline $\begin{array}{l}\text { Financial } \\
\text { concerns }\end{array}$ & $19.66 \pm 6.82$ & $23.17 \pm 6.93$ & 0.001 \\
\hline HIV awareness & $35.24 \pm 10.63$ & $36.11 \pm 11.44$ & 0.763 \\
\hline Life satisfaction & $34.44 \pm 9.12$ & $34.44 \pm 8.96$ & 0.702 \\
\hline $\begin{array}{l}\text { Medication } \\
\text { concerns }\end{array}$ & $34.05 \pm 10.45$ & $36.53 \pm 6.54$ & 0.282 \\
\hline $\begin{array}{l}\text { Confidence in } \\
\text { the professional }\end{array}$ & $14.93 \pm 10.45$ & $15.97 \pm 11.25$ & 0.668 \\
\hline \multicolumn{4}{|c|}{ *: MannWhitney test } \\
\hline
\end{tabular}

Table 2. Comparison of domains of the HAT-QoL scale between groups at the end of nursing consultation monitoring.

\begin{tabular}{|c|c|c|c|}
\hline Domains & $\begin{array}{l}\text { Exposed } \\
\text { group } \\
\text { Mean + SD }\end{array}$ & $\begin{array}{c}\text { Non-exposed } \\
\text { group } \\
\text { Mean + SD }\end{array}$ & p-value* \\
\hline $\begin{array}{l}\text { General } \\
\text { activities }\end{array}$ & $49.60 \pm 7.86$ & $42.97 \pm 0.002$ & 0.002 \\
\hline Sexual activities & $36.57 \pm 8.97$ & $38.61 \pm 8.61$ & 0.382 \\
\hline $\begin{array}{l}\text { Confidentiality } \\
\text { concerns }\end{array}$ & $29.58 \pm 13.90$ & $25.33 \pm 11.44$ & 0.268 \\
\hline Health concerns & $45.69 \pm 10.15$ & $33.50 \pm 8.82$ & 0.000 \\
\hline $\begin{array}{l}\text { Financial } \\
\text { concerns }\end{array}$ & $19.27 \pm 11.98$ & $26.87 \pm 8.06$ & 0.001 \\
\hline HIV awareness & $47.45 \pm 5.20$ & $39.44 \pm 6.16$ & 0.000 \\
\hline Life satisfaction & $17.88 \pm 6.58$ & $30.83 \pm 5.90$ & 0.000 \\
\hline $\begin{array}{l}\text { Medication } \\
\text { concerns }\end{array}$ & $33.48 \pm 6.30$ & $38.23 \pm 6.58$ & 0.069 \\
\hline $\begin{array}{l}\text { Confidence in } \\
\text { the professional }\end{array}$ & $6.94 \pm 11.29$ & $7.58 \pm 8.75$ & 0.032 \\
\hline
\end{tabular}


Table 3. Comparison of domains of the HAT-QoL scale between first nursing consultation and end of nursing consultation monitoring in the exposed group.

\begin{tabular}{|c|c|c|c|}
\hline \multirow[b]{2}{*}{ Domains } & \multicolumn{2}{|c|}{ Exposed group } & \multirow[b]{2}{*}{ p-value* } \\
\hline & $\begin{array}{c}\text { Before } \\
\text { Mean + SD }\end{array}$ & $\begin{array}{c}\text { After } \\
\text { Mean + SD }\end{array}$ & \\
\hline $\begin{array}{l}\text { General } \\
\text { activities }\end{array}$ & $34.30 \pm 10.01$ & $49.60 \pm 7.86$ & 0.000 \\
\hline Sexual activities & $39.06 \pm 8.79$ & $36.57 \pm 8.97$ & 0.167 \\
\hline $\begin{array}{l}\text { Confidentiality } \\
\text { concerns }\end{array}$ & $17.18 \pm 14.21$ & $29.58 \pm 13.90$ & 0.000 \\
\hline Health concerns & $20.62 \pm 11.32$ & $45.69 \pm 10.15$ & 0.000 \\
\hline $\begin{array}{l}\text { Financial } \\
\text { concerns }\end{array}$ & $19.66 \pm 6.82$ & $19.27 \pm 11.98$ & 0.505 \\
\hline HIV awareness & $35.24 \pm 10.63$ & $47.45 \pm 5.20$ & 0.000 \\
\hline Life satisfaction & $34.44 \pm 9.12$ & $17.88 \pm 6.58$ & 0.000 \\
\hline $\begin{array}{l}\text { Medication } \\
\text { concerns }\end{array}$ & $34.05 \pm 6.37$ & $33.48 \pm 6.30$ & 0.763 \\
\hline $\begin{array}{l}\text { Confidence in } \\
\text { the professional }\end{array}$ & $14.93 \pm 10.45$ & $6.94 \pm 7.58$ & 0.000 \\
\hline
\end{tabular}

compared after the nursing consultation (Table 2). There was improvement in the quality of life in the following domains of the exposed group: general activities ( $p=0.002)$, health concerns $(p=0.000)$, HIV awareness ( $p=0.000)$, life satisfaction ( $p=$ $0.000)$ and professional reliability ( $p=0.032)$. In relation to financial concerns, there was a decrease in the mean of the exposed group and a significant increase in the non-exposed group ( $p=0.001$ ).

Since this study aimed to evaluate the influence of the nursing consultation built upon Orem, between the two groups, comparison of the means of each domain of the HAT-QoL scale at the beginning of treatment, and after the last consultation in the TB ambulatory clinic, was performed for the exposed group (Table 3).

Among individuals followed by nursing consultation using the Orem foundation, significant improvement was evidenced at the end of the monitoring in the domains: health concerns $(p=0.000)$, general activity $(p=0.000)$, life satisfaction $(p=0.000)$, HIV awareness ( $p=0.000)$, and confidentiality concern $(p=0.000)$.

\section{Discussion}

Considering that HIV/Aids infection has assumed a chronic character, mainly after the introduction of HAART [1], there is a misguided correlation between QoL of seropositive patients and the correct use of medications, in which it was stated that QoL is a consequence of the correct use of medications. Yet, QoL does not refer only to use of medication; it is also related to other aspects of peoples' lives.

Studies $[1,9,10]$ revealed better quality of life of HIVIAIDS patients in the asymptomatic stage than of patients in advanced stages, as well as in those with opportunistic diseases.

A study compared QoL of seropositive patients that had TB associated with HIVIAIDS with those who did not. The authors observed QoL was 60\% lower in patients with TB (excluding latent TB) when compared to asymptomatic TB patients $[5,11]$. In this study, the majority of people were in the advanced stage of the disease, which was evidenced by a low mean count of T CD4+ lymphocytes (below 350 cells $/ \mathrm{mm}^{3}$ ) and by TB symptoms. Such aspects affect the routine of patients and prevent them from performing day-to-day activities, compromising their lives.

Also, many patients discovered their HIV serological status near or at the same time as their positive TB results, and stages of grief, primarily denial, fear and anger were perceived, damaging their acceptance of the current situation. A study demonstrated similar results, in which TB patients newly diagnosed as seropositive developed significant depression and fear of stigma [11].

The prevalence of low family income was detected in the financial concerns domain. This concern affected the survival of the subjects, the sustenance of family, and the continuity of the treatment, 
having as a consequence a worsening of QoL. Economic status plays an important role in the quality of people's lives because it involves the conflict between self-support and the difficult access to employment and income, due to lack of physical conditions relevant to illness, fear of prejudice, or low education and qualification [9].

Brazilian researchers $[5,8,10,12,13,14]$ found that better levels of quality of life of HIV patients were related to better financial conditions, as with the results of the present study. Other study [15], also showed better QoL indicators associated with increased income.

With regard to concerns about confidentiality related to the infection, this may be associated with fear of the carrier or patient, to make their diagnosis known, to suffer prejudice and stigmatization. In this sense, most of the seropositive individuals hid the fact that they were contaminated for as long and in the best possible manner, becoming clandestine about their condition. The patients attempted to circumvent the social isolation, to which they could be subjected in most cases if they declared they were HIV positive [14]. This method used by the subjects as a form of hiding the HIV infection has the intent of protecting their relatives and their children from possible rejection, stigma and discrimination; the method is also utilized to protect them from possible job dismissal arising from prejudice [16].

Health concerns were observed in other studies $[14,16]$ and were related to patient knowledge about immunity parameters (CD4 cell count) and the consequences of altered levels, leading to preoccupations with prognosis of imminent death, affecting their welfare.

Patients reported decreased sexual activities due to fear, because of the possibility of HIV and tuberculosis transmission through sexual intercourse. Concomitantly, another aspect influencing sexual interest was physical weakness imposed by illness, primarily in the case of $\mathrm{TB}$, in which feeling of weakness hindered social and sexual relations $[10,17]$.
It was observed that the loss QoL in both groups, from the beginning of the research, reflected physical aspects such as the inability to work and perform daily activities, as well as the psychological aspects related to the fear of illness, death and prejudice. However, interventions promoting and enabling clients to provide self-care enhanced the QoL. This improvement was verified through analysis of the trust patients placed in the professionals, motivated by an attuned therapeutic relationship. This is fundamental to continuity of treatment and client follow-up. Corroborating this, a more holistic approach, which was not confined to coinfection treatment, was beneficial to the QoL [15].

Regarding QoL indicators observed by the HATQoL at the end of TB treatment, significant improvement was noted, with the exception of sexual function and financial concerns, as they represented striking situations in the lives of adults. For some patients, financial status was essential to achieve a minimum of dignity and survival. Financial status, along with sexual relationships, motivates patients' lives with partners.

The present study sustains the positive interference of the nursing consultation model on the QoL of individuals with HIV/TB. Additionally, the use of QoL as an indicator is essential to ensure that the application of nursing consultation using a theoretical model enables the assistance and promotion of care that encompasses issues demonstrated to be harmful to the lives of individuals.

The concept of QoL is subjective and is represented by physical, emotional and social aspects; the knowledge and competence to help individuals in the quest to maintain or improve levels of this quality are implicitly included in the Orem model [18].

Although the nursing consultation proposed and used in this study contributed significantly to improving the quality of life of patients, the vast majority of areas assessed, even after intervention, did not reach the score of reference stipulated. However, a research [19] showed similar aspects, when detec- 
ting that at the end of treatment for TB, physical function improved rapidly while the integrity of the psychological wellbeing persisted for a long period. As the authors emphasized, although considered microbiologically cured, patients remained poor and afraid of social stigma, thus with impaired quality of life.

Regarding the issues of poverty and lack of social support, there are limitations to performance of health professionals, including nurses. Yet nursing contributes to improving these aspects from the perspective of health promotion, through interdisciplinary and inter-institutional work [20]. Despite the success of tuberculosis treatment, these patients continue to live with HIVIAIDS, and therefore, with the ghost of prejudice and illness.

\section{Ethical standards}

This study was approved by the Brazilian Ethics and Research Committee (CONEP), protocol number CAAE 0037.0.042.000-09.

\section{Conflict of interest}

The authors assert no conflicts of interest.

\section{References}

1. Deribew A, Deribe K, Reda AA, Tesfaye M, Hailmichael Y, Maja T, Colebunders R. Change in quality of life: a follow up study among patients with HIV infection with and without TB in Ethiopia. BMC Public Health [Internet]. 2013 [cited 2015 aug 23]; 13: 408. Available from: http://bmcpublichealth.biomedcentral. com/articles/10.1186/1471-2458-13-408

2. Lee C, Hwang J, Oh D, Kee M, Oh E, An J, et al. The burden and characteristics of tuberculosis/human immunodeficiency virus (TB/HIV) in South Korea: a study from a population database and a survey. BMC Infect Dis [Internet]. 2010 [cited 2015 aug 23]; 10:66. Available from: http://bmcinfectdis.biomedcentral. com/articles/10.1186/1471-2334-10-66

3. Lacerda SNB, Figueiredo TMRM, Luna FDT, Temoteo RCA, Silva EL, Abreu LC, et al. Vulnerability aspects that hinder tuberculosis healing according to the perspective of patients and healthcare managers. Int Arc Med. [Internet]. 2015 [cited Oct 2015]; 8:48. Available from: http://imed.pub/ojs/index.php/iam/ article/view/1023/742
4. Dean HD, Fenton KA. Addressing social determinants of health in the prevention and control of HIV/AIDS, viral hepatitis, sexually transmitted infections and tuberculosis. Public Health Rep [Internet]. 2010 [cited Oct 2015]; 125(Suppl 4):1-5. Available from: http://www.ncbi.n/m.nih.gov/pmc/articles/PMC2882967/

5. Lemos LA, Feijão AR, Gir E, Galvão MTG. Quality of life aspects of patients with HIV/tuberculosis co-infection. Acta Paul Enferm [Internet]. 2012 [cited Oct 2015]; 25(spe1):41-7. Available from: http://www.scielo.br/pdf/ape/v25nspe1/07.pdf

6. Curcio R, Lima MHM, Torres HC. Elaboration for nursing consultation: focus on the treatment with insulin. Rev Gaúcha Enferm [Internet]. 2009 [cited Oct 2015]; 30:552-7. Available from: http://www.seer.ufrgs.br/RevistaGauchadeEnfermagem/ article/viewFile/7987/6998

7. Brasil. Ministério da Saúde. Programa Nacional de Combate à Tuberculose. Manual de recomendações para o controle da tuberculose no Brasil. Brasília: Ministério da Saúde; 2010.

8. Soárez PC, Castelo A, Abrão P, Holmes WC, Ciconelli RM. Tradução e validação de um questionário de avaliação de qualidade de vida em AIDS no Brasil. Rev Panam Salud Publica, [Internet]. 2009 [citado out 2015]; 25:69-76. Disponível em: http://www.scielosp.org/pdf/rpsp/v25n1/11.pdf

9. Carneiro AKJ. Avaliação da qualidade de vida dos pacientes com sorologia positiva para HIV, acompanhados ambulatorialmente no Instituto de Infectologia Emílio Ribas. Dissertação (Mestrado), Programa de Pós-Graduação em Ciências da Coordenadoria de Controle de Doenças, São Paulo, Brasil, 2010.

10. Neves, LAS, Canini SRM, Reis RK, Santos CB, Gir, E. Aids and tuberculosis: coinfection from the perspective of the quality of life of patients. Rev Esc Enferm USP [Internet]. 2012 [cited Oct 2015]; 46(3):704-10. Available from: http://www.scielo.br/pdf/ reeusp/v46n3/en 24.pdf

11. Deribew A, Tesfaye M, Hailmichael $Y$, Negussu N, Daba S, Wogi A, et al. Tuberculosis and HIV coinfection: its impact on quality of life. Health Qual Life Outcomes [Internet]. 2009 [cited Oct 2015]; 7:105. Available from: http://hqlo.biomedcentral.com/ articles/10.1186/1477-7525-7-105

12. Sousa SS, Silva DMGV. Experiencing treatment for tuberculosis. Texto Contexto Enferm [Internet]. 2010 [cited Oct 2015]; 19(4):636-43. Available from: http://www.scielo.br/pdf/tce/ $\underline{\mathrm{v} 19 \mathrm{n} 4 / 05 . \mathrm{pdf}}$ 
13. Dowdy DW, Israel G, Vellozo V, Saraceni V, Cohn S, Cavalcante S, Durovni B. Quality of life among people treated for tuberculosis and human immunodeficiency virus in Rio de Janeiro, Brazil. Int J Tubercs Lung Dis [Internet]. 2013 [cited Oct 2015]; 17:3457. Available from: http://www.ncbi.nlm.nih.gov/pmc/articles/ PMC3718256/

14. Galvão MTG, Cerqueira ATAR, Marcones-Machado J. Avaliação da qualidade de vida de mulheres com HIVIAIDS através do HAT-QoL. Cad Saúde Pública [Internet]. 2004 [cited Oct 2015]; 20:430-7. Available from: http://www.scielo.br/scielo. php?script=sci arttext\&pid=S0102-311X2004000200010

15. Kittikraisak W, Kingkaew $P$, Teerawattananon $Y$, Yothasamut J, Natesuwan S, Manosuthi W, et al. Health related quality of life among patients with tuberculosis and HIV in Thailand. PloS ONE [Internet]. 2012 [cited Oct 2015]; 7, e29775. Available from: http://journals.plos.org/plosone/article?id=10.1371/journal. pone.0029775

16. Seoane AF, Fortes PAC. The Family Health Program users' perception of the privacy and confidentiality of their information. Saúde Soc [Internet]. 2009 [cited Oct 2015]; 18:42-9. Available from: $\quad$ http://www.scielo.br/scielo.php?script=sci arttext\&pid $=$ S0104-12902009000100005

17. Gao L, Zhou F, Li X, Jin Q. HIV/TB co-infection in Mainland, China: a meta-analysis. PloS ONE [Internet]. 2010 [cited Oct 2015]; 5:1-6. Available from: http://journals.plos.org/plosone/ article?id=10.1371/journal.pone.0010736

18. Orem DE. Nursing: concepts of practice. St. Louis: Mosley; 1995.

19. Guo N, Marra F, Marra CA. Measuring health-related quality of life in tuberculosis: a systematic review. Health Qual Life Outcomes [Internet]. 2009 [cited Oct 2015]; 7:14. Available from: http://hqlo.biomedcentral.com/articles/10.1186/1477-7525-7-14

20. Oblitas FYM, Loncharich N, Salazar ME, David HML, Silva I, Velásquez D. Nursing's role in tuberculosis control: a discussion from the perspective of equity. Rev Latino-Am Enfermagem [Internet]. 2010 [cited Oct 2015]; 18(1): 130-8. Available from: http://www.scielo.br/pdf/rlae/v18n1/20.pdf
Publish in International Archives of Medicine

International Archives of Medicine is an open access journal publishing articles encompassing all aspects of medical science and clinical practice. IAM is considered a megajournal with independent sections on all areas of medicine. IAM is a really international journal with authors and board members from all around the world. The journal is widely indexed and classified Q1 in category Medicine. 